\title{
Response of Kientzler New Guinea Impatiens to Manual and Chemical Pinching
}

\section{Terri Woods Starman \\ Department of Plant and Soil Science, Southern Illinois University, Carbondale, IL 62901}

Additional index words. dikegulac, shoot apex removal

Abstract. Manually and chemically pinched plants of 18 cultivars of Impatiens hybrids (Kientzler New Guinea impatiens) were compared to control plants to determine the effect of shoot apex removal on flowering, plant size, and branching characteristics. Either pinching treatment delayed flowering by $\approx 3$ days compared with nonpinched controls. Pinching had no effect on plant height or fresh or dry weight. Plant diameter and form changes due to pinching depended on cultivar. Total branch count was increased by chemical but not manual pinching although both pinching methods affected mode of branching. The 18 cultivars of Kientzler New Guinea impatiens were best grown as 0.4-liter potted plants without the aid of pinching.

New Guinea impatiens were brought to the United States from Australian New Guinea during a U.S. Dept. of Agriculture/Longwood Foundation cosponsored plant exploration in 1970 (Winters, 1973). In 1972, introductions were released by the U.S. Dept. of Agriculture and distributed to plant breeders (Arisumi and Cathey, 1976). L. Keintzler introduced his series of New Guinea impatiens cultivars in 1987 (Larson, 1989).

Due to the recent introduction of this series of New Guinea impatiens, it was necessary to determine whether plant growth habit would be sufficiently compact to obtain a desirable plant form for small-container culture. If not, plant dimensions might be altered or improved by pinching, a standard horticultural practice. Pinching could reduce plant height or increase diameter or produce a better-branched, denser plant.

Pinching may be accomplished by manual removal of shoot apices, which overcomes apical dominance and increases lateral branching but is a labor-intensive method. Alternatively, pinching may be achieved chemically with a foliar spray of 2,3:4,6-bis0 -(1-methylethylidene) $\alpha$-L-xylo-2-hexulofuranosonic acid (dikegulac), a compound that is translocated to the shoot apex, temporarily arresting apical development and stimulating lateral branching (Arzee et al., 1977). Dikegulac increased axillary shoot production of azaleas (Larson, 1978; Shu and Sanderson, 1980), zinnia and chrysanthemum (Arzee et al., 1977), and Rieger begonia (Agnew and Campbell, 1983), but was proven ineffective on some foliage plant species (Lyons and Hale, 1987).

Received for publication 20 July 1990. The author thanks Paul Ecke Poinsettias for the donation of plants, and Estella Auerswald and Barbara Garrison for their technical assistance. The cost of publishing this paper was defrayed in part by the payment of page charges. Under postal regulations, this paper therefore must be hereby marked advertisement solely to indicate this fact.
The objective of this study was to determine whether manual or chemical pinching was needed to alter the dimensions of Kientzler New Guinea impatiens to more desirable proportions when grown in 0.4-liter containers and whether flowering and branching would be affected by pinching.

Rooted cuttings of 18 cultivars of Kientzler New Guinea impatiens were planted on 9 Mar. 1989, one cutting per 0.4-liter plastic container, using Pro-Mix BX (Premier Brands, New Rochelle, N.Y.). Plants were fertilized at each irrigation using Peters' water soluble fertilizer $20 \mathrm{~N}-4.4 \mathrm{P}-16.6 \mathrm{~K}$ (W.R.

Table 1. Effect of pinching on the number of primary branches of 18 cultivars of Kientzler New Guinea impatiens.

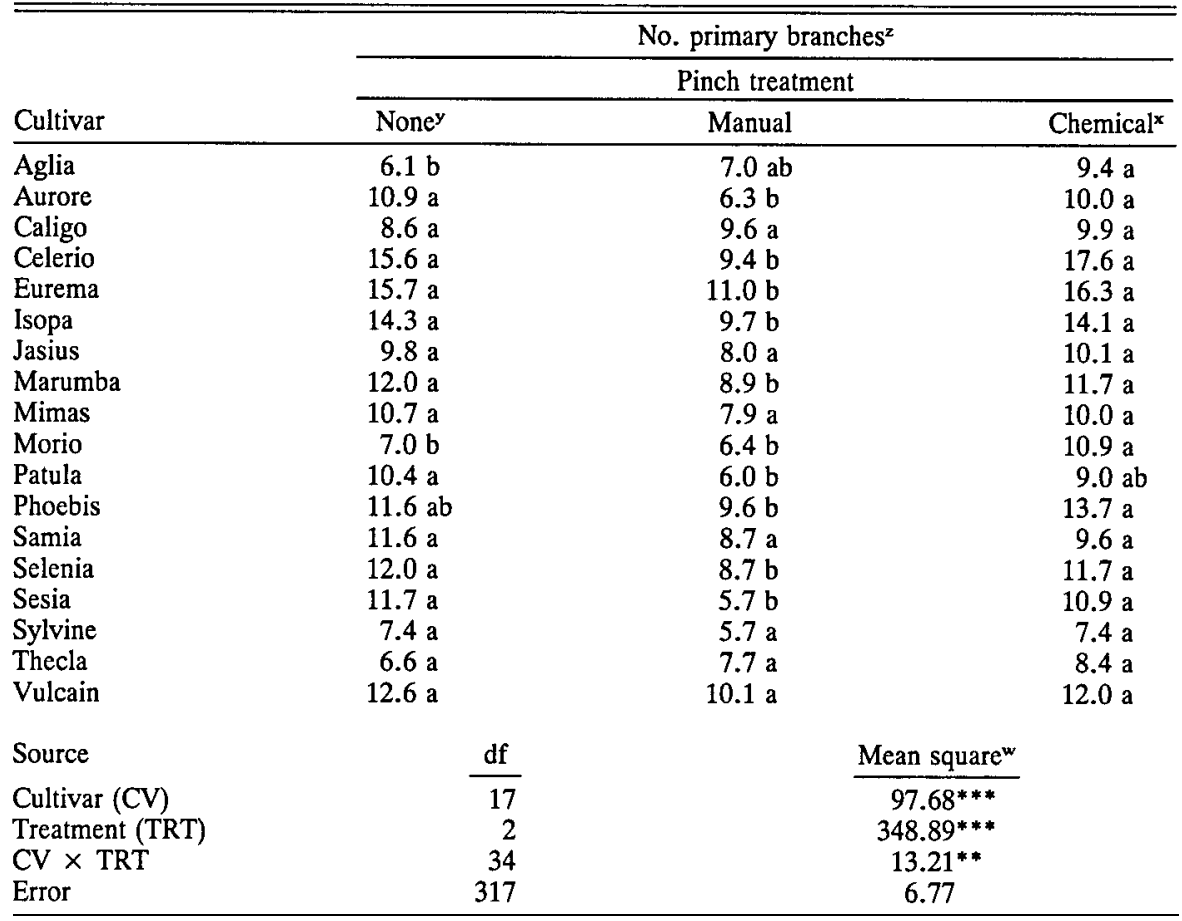

${ }^{2}$ Mean separation in rows by Duncan's multiple range test, $P=0.05$.

'Control.

'Dikegulac (780 mg.liter $\left.{ }^{-1}\right)$.

"F tests for two-way analysis significant at $0.01 \geq \alpha>0.001$ (**) $^{\text {or }} \alpha \leq 0.001$ (***). 
Table 2. Effect of pinching on the number of primary branches per node, and on the number of secondary and total branches for 18 cultivars of Kientzler New Guinea impatiens.

\begin{tabular}{|c|c|c|c|c|}
\hline $\begin{array}{l}\text { Pinch } \\
\text { treatment }\end{array}$ & & $\begin{array}{l}\text { Primary branches } \\
\text { per node } \\
\text { (no.) }\end{array}$ & $\begin{array}{l}\text { Secondary } \\
\text { branches } \\
\text { (no.) }\end{array}$ & $\begin{array}{l}\text { Total } \\
\text { branches } \\
\text { (no.) }\end{array}$ \\
\hline $\begin{array}{l}\text { None (control) } \\
\text { Manual } \\
\text { Chemicaly } \\
\text { Source }\end{array}$ & $\mathrm{df}$ & $\begin{array}{l}1.9 \mathrm{c}^{2} \\
4.0 \mathrm{a} \\
2.2 \mathrm{~b}\end{array}$ & $\begin{array}{r}12.9 \mathrm{~b} \\
16.3 \mathrm{a} \\
15.8 \mathrm{a} \\
\text { Mean square }\end{array}$ & $\begin{array}{l}24.4 \mathrm{~b} \\
26.6 \mathrm{~b} \\
30.2 \mathrm{a}\end{array}$ \\
\hline $\begin{array}{l}\text { Cultivar (CV) } \\
\text { Treatment (TRT) } \\
\text { CV } \times \text { TRT } \\
\text { Error }\end{array}$ & $\begin{array}{r}17 \\
2 \\
34 \\
317^{\mathrm{w}}\end{array}$ & $\begin{array}{c}4.77^{* * *} \\
83.21^{* * *} \\
0.68^{\text {Ns }} \\
0.60\end{array}$ & $\begin{array}{c}518.74^{* * *} \\
401.03^{* * *} \\
48.64^{N s} \\
34.47\end{array}$ & $\begin{array}{c}1050.00^{* * *} \\
1161.09^{* * *} \\
99.48^{\text {NS }} \\
78.86\end{array}$ \\
\hline
\end{tabular}

${ }^{2}$ Mean separation within columns by Duncan's multiple range test, $P=0.05$.

yDikegulac $\left(780 \mathrm{mg} \cdot\right.$ liter $\left.^{-1}\right)$.

${ }^{\times} \mathrm{F}$ tests for two-way analyses significant at $\alpha \leq 0.001\left({ }^{* * *}\right)$ or nonsignificant (NS).

${ }^{w} \mathrm{df}=258$ for primary branches per node.

Table 3. Effect of pinching on the number of tertiary branches of five cultivars of Kientzler New Guinea impatiens.

\begin{tabular}{|c|c|c|c|c|}
\hline \multirow[b]{2}{*}{ Cultivar } & \multicolumn{4}{|c|}{ Pinch treatment } \\
\hline & None $^{z}$ & Manual & & Chemicaly \\
\hline & & $N o{ }^{x}$ & & \\
\hline Aurore & $1.1 \mathrm{~b}$ & $8.6 \mathrm{a}$ & & $10.1 \mathrm{a}$ \\
\hline Jasius & $1.3 \mathrm{~b}$ & $1.1 \mathrm{~b}$ & & $7.9 \mathrm{a}$ \\
\hline Patula & $2.7 \mathrm{~b}$ & $3.9 \mathrm{~b}$ & & $18.5 \mathrm{a}$ \\
\hline Samia & $2.3 \mathrm{~b}$ & $12.1 \mathrm{a}$ & & $4.0 \mathrm{~b}$ \\
\hline Selenia & $0.0 \mathrm{~b}$ & $0.4 \mathrm{~b}$ & & $7.1 \mathrm{a}$ \\
\hline Source & $\mathrm{df}$ & & Mean squarew & \\
\hline Cultivar (CV) & 17 & & $117.05^{* * *}$ & \\
\hline Treatment (TRT) & 2 & & $233.91 * * *$ & \\
\hline $\mathrm{CV} \times \mathrm{TRT}$ & 34 & & $47.59^{* *}$ & \\
\hline Error & 317 & & 23.72 & \\
\hline
\end{tabular}

${ }^{2}$ Control.

yikegulac (780 $\left.\mathrm{mg} \cdot \mathrm{liter}{ }^{-1}\right)$.

'Mean separation in rows by Duncan's multiple range test, $P=0.05$.

${ }^{w} \mathrm{~F}$ tests for two-way analysis significant at $0.01 \geq \alpha>0.001\left({ }^{* *}\right)$ or $\alpha \leq 0.001\left({ }^{* * *}\right)$.

of the plant, and plant diameter was measured across the top of the plant. A plant form ratio was calculated by dividing plant height by diameter. Fresh weight was measured gravimetrically at time of harvest and dry weight after $72 \mathrm{~h}$ at $80 \mathrm{C}$. Primary branch count was taken as the number of branches that originated from the main stem. Secondary and tertiary branches were those that originated from the primary and secondary branches, respectively. Total branch count was the sum of all branches. Dividing the primary branch count by the number of nodes on the main stem yielded the primary branch count per node.

Dikegulac at $1560 \mathrm{mg} \cdot \mathrm{liter}^{-1}$ decreased plant height and diameter to an extreme degree, and flowering was delayed or inhibited (data not shown). In addition, leaf and flower size were reduced and the flowers had narrow and pointed petals. This response to high concentrations of dikegulac has been noted previously (Arzee et al., 1977; Larson, 1978). At this concentration, tertiary branch count was increased and branch size was reduced to such an extent that an accurate branch count was impossible to determine by our method. This treatment would not be recommended and was eliminated from the analysis.

All cultivars responded the same to pinch treatments in regard to time to flower, plant height, and fresh and dry weight (data not shown). Both pinching methods delayed time to flower by $\approx 3$ days compared with control plants (69 vs. 66 days). Neither pinching method affected plant height or fresh and dry weight of any cultivar.

In most cultivars, pinching had no effect on either plant diameter or form (data not shown). Where effects were shown, they were inconsistent. For example, pinching either decreased ('Patula' and 'Sylvine') or increased ('Thecla') plant diameter and increased ('Sylvine') or decreased ('Thecla') the plant form ratio. The ideal ratio for floricultural crops has been defined to be overall plant height (plant plus container)/plant diameter at the plant top $=1.6$ (Sachs et al., 1976). When plant height was $>2.0$ times the diameter, dense foliar canopy provided an acceptable appearance. Plant form ratios for control plants of the 18 cultivars ranged from 0.72 to 1.20 .

There was an interaction between cultivar and treatment for primary branch count (Table 1). Primary branch count was decreased by manual pinching in eight cultivars, increased by chemical pinching in two cultivars, and not affected by pinching in the other eight relative to the control.

There was no interaction between cultivar and treatment for primary branch count per node or secondary and total branch counts
(Table 2). Primary branch count per node was increased more by manual pinching than by chemical pinching. The increase in manually pinched plants was due to fewer or the same number of primary branches being initiated from fewer nodes compared with control plants $(2.0$ nodes \pm 0.30 SD vs. 6.0 nodes $\pm 1.06 \mathrm{SD}$ ). Increases in primary branch count per node for chemically pinched plants were not due to fewer main stem nodes (5.3 nodes $\pm 1.05 \mathrm{SD})$. These results indicate that dikegulac temporarily inhibited, but did not totally arrest, apical meristem development. Overall, the secondary branch count increased by $\approx 3$ branches for all cultivars when plants were pinched. The total branch count was increased only by chemical pinching.

Plants of 'Aurore', 'Jasius', 'Patula', and 'Selenia', which were pinched with dikegulac, had more tertiary branches than the controls (Table 3). This increase also occurred when 'Aurore' was pinched manually. Only manual pinching increased tertiary branch count of 'Samia'. Tertiary branch count was unaffected for any other cultivar.

Pinching delayed time to flower, had minimal effect on plant size, and altered branching characteristics. The only observed implication of the change in mode of branching on plant appearance at harvest was the tendency of some manually pinched plants to look more flat and less floriferous in the center of the plant. This characteristic was due to the absence of flowers borne at the terminal of the main (pinched) stem compared with those present on control plants. All 18 cultivars of Kientzler New Guinea impatiens had desirable plant size characteristics without the aid of pinching when grown as 0.4-liter plants and harvested 10 weeks after planting. Thus, the Kientzler New Guinea impatiens cultivars tested in this study should not be pinched if grown as 0.4-liter potted plants.

\section{Literature Cited}

Agnew, N.H. and R.W. Campbell. 1983. Growth of Begonia $\times$ hiemalis as influenced by handpinching, dikegulac, and chlormequat. HortScience 18:201-202.

Arisumi, T. and H.M. Cathey. 1976. The New Guinea impatiens. HortScience 11:2.

Arzee, T., H. Langnauer, and J. Gressel. 1977. Effects of dikegulac, a new growth regulator, on apical growth and development of three Composite. Bot. Gaz. 138:18-28.

Larson, R.A. 1978. Stimulation of lateral branching of azaleas with dikegulac-sodium (Atrinal). J. Hort. Sci. 53:57-62.

Larson, R.A. 1989. West German New Guinea impatiens experts visit Raleigh. North Carolina Flower Growers Bul. 34(2):11.

Lyons, R.E. and C.L. Hale. 1987. Comparison of pinching methods on selected species of $\mathrm{Col}$ umnea, Kalanchoe, and Crassula. HortScience 22:72-74.

Sachs, R.M., A.M. Kofranek, and W.P. Hackett. 1976. Evaluating new pot plant species. Florists Rev. 159(4116):35-36, 80-84.

Shu, L. and K. Sanderson. 1980. Dikegulac sodium influences shoot growth of greenhouse azaleas. HortScience 15:813-814.

Winters, H.F. 1973. New impatiens from New Guinea. Amer. Hort. 52:16-22. 